\title{
Pemberian Latihan Rentang Gerak Terhadap Fleksibilitas Sendi Anggota Gerak Bawah Pasien Fraktur Femur Terpasang Fiksasi Interna Di RSUP. Dr. M. Djamil Padang
}

\author{
Reni Prima Gusty (Fakultas keperawatan Unand) \\ Armayanti (RSUD M Djamil Padang) \\ email : renigusty@gmail.com
}

\begin{abstract}
ABSTRAK : Gangguan fleksibilitas sendi anggota gerak bawah merupakan masalah yang sering terjadi pada pasien fraktur femur pasca operasi pemasangan fiksasi interna. Upaya yang dapat dilakukan untuk mencegah gangguan ini dintaranya adalah melakukan latihan rentang gerak sendi sedini mungkin. Tujuan penelitian adalah mengetahui pengaruh pemberian latihan rentang gerak terhadap kelenturan sendi anggota gerak bawah pada pasien fraktur femur terpasang fiksasi interna. Rancangan penelitian menggunakan Quasy Eksperiment dengan pendekatan Posttest Only Control Group. Sampel adalah pasien fraktur femur post fiksasi interna hari ke dua sebanyak 20 responden, dibagi dalam dua kelompok yaitu 10 responden mendapat latihan rentang gerak (eksperimen) dan 10 responden melakukan latihan rentang gerak tidak sesuai aturan penelitian (kontrol). Instrument menggunakan goniometer. Perlakuan Latihan gerak dilakukan 2 kali sehari pagi dan sore hari selama 5 hari dengan durasi 15 menit. Data dianalisa dengan uji statistik Mann Whitney. Hasil penelitian pada kelompok eksperimen didapatkan rata-rata kelenturan sendi setelah diberikan latihan rentang gerak yaitu fleksi sendi panggul 68,5 derajat, fleksi sendi lutut 61 derajat, dorsofleksi pergelangan kaki 12,5 derajat dan plantarfleksi pergelangan kaki 47 derajat, sedangkan pada kelompok kontrol didapatkan rata-rata fleksi sendi panggul 45,5 derajat, fleksi sendi lutut 15,5 derajat, dorsofleksi 1,5 derajat dan plantarfleksi 33,5 derajat. Berdasarkan uji statistik Mann Whitney didapatkan p=0,000 $<0,05$ yang menunjukkan ada perbedaan derajat kelenturan sendi pada kelompok eksperimen dibanding dengan kelompok kontrol. Kesimpulan lebih besar peningkatan derajat kelenturan sendi pada kelompok eksperimen dibanding dengan kelompok kontrol. Disarankan lakukan latihan gerak sendi post operasi fiksasi hari kedua (sedini mungakin) sehingga dapat mencegah terjadinya kekakuan pada sendi pada pasien fraktur femur terpasang fiksasi interna.
\end{abstract}

Kata Kunci : Fraktur femur, fiksasi interna, fleksibilitas sendi, latihan rentang gerak.

ABSTRACT : The disturbance of the flexibility of below range of motion joint is one of the problem that common occur to the Femur Fracture in Patients post-operation lighted Interna Fixation. The attempt to prevent it is doing range of motion. The goal of this research to know the influence of giving range of motion regarding to the Femur Fractures patient lighted Interna fixation. The design of the research is using Quasy Experiment and Posttest Only Control Group Design. The numbers of the samples are 20 fraktur femur patients. Divided into 2 groups : 10 patients get the motion extension training (experiment), 10 patients do the motion extension training not in control (control). The research has been done in 16 October 2012 - Jun 2013, collecting the data have been done in 16 march 2013 - 13 April 2013. The result of the research, the experiment group gets the averages of hinge flexibility after giving the range of motion, hip joint flexibility 68,5 degrees, knee joint flexibility 61 degrees, dorsoflexy ankle joint 12,5 degrees and plantarflexy ankle joint 47 degrees, and the control group gets the averages of joint flexibility, hip joint flexibility 45,5 degrees, knee joint flexibility 15,5 degrees, dorsoflexy 1,5 degrees and platarflexy 33,5 degrees. Based on Mann Whitney statistic test show that there are significant differences range of motion between experiment group and control group. Conclusion: giving the range of motion can prevent the disturbance of joint flexibility to the Femur Fractures patients lighted interna fixation

Key words : Femur Fractures, post-operation, hinge flexibility, motion extension

training.

Bibliography : 34 ( 1993-2012) 
Fraktur adalah terputusnya kontinuitas jaringan tulang dan / atau tulang rawan yang umumnya disebabkan oleh rudapaksa (Sjamsuhidajat \& Jong, 2005). Fraktur femur adalah suatu patahan pada kontinuitas struktur tulang paha yang ditandai adanya deformitas yang jelas yaitu pemendekan tungkai yang mengalami fraktur dan hambatan mobilitas fisik yang nyata (Muttaqin, 2008). Fraktur dapat terjadi akibat peristiwa trauma langsung, tekanan yang berulang-ulang, dan kelemahan abnormal pada tulang (fraktur patologik) (Salamon dkk, 1995). Fraktur terbagi atas fraktur komplet, fraktur tidak komplet, fraktur tertutup, fraktur terbuka, dan fraktur patologis. Fraktur bisa terjadi didaerah cranium, thorak, pelvis, anggota gerak atas, dan anggota gerak bawah. Prinsip penanganan fraktur meliputi reduksi, imobilisasi, pengembalian fungsi, dan kekuatan normal dengan rehabilitasi. Reduksi dapat dilakukan secara terbuka maupun tertutup. Reduksi terbuka (open reduksi) dilakukan melalui pembedahan dengan cara memasukkan alat fiksasi berupa plat, screw, wire atau pin kedalam tulang. Fiksasi dapat dilaksanakan secara interna maupun ekterna, tergantung dari bentuk frakturnya (Smeltzer \& Bare, 2002).

A fracture is a break of continuity of bone tissue and / or cartilage which is generally caused by involuntary (Sjamsuhidajat \& Jong, 2005). Femoral fracture is a fracture in the continuity of the femur structure characterized by a clear deformity that is shortening the leg fracture and a real physical mobility barriers (Muttaqin, 2008). Fractures may occur as a result of direct trauma events, repetitive stress, and abnormal weakness on bone (pathologic fracture) (Salamon et al, 1995). Divided into fracture complete fracture, the fracture is not complete, closed fractures, open fractures, and pathologic fractures. Fractures can occur areas cranium, thoracic, pelvic, upper limbs and lower limbs Principles of fracture treatment include reduction, immobilization, return of function, and normal strength with rehabilitation. Reduction can be done in open or closed. Open reduction (open reduction) is done surgically by inserting fixation devices such as plates, screws, wire or pin into the bone. Internal fixation can be carried out and ekterna, depending on the shape of the fracture (Smeltzer \& Bare, 2002).

Fiksasi interna (open reduksi internal fiksasi) adalah metode pembedahan memperbaiki fraktur dengan menggunakan plate dan screw atau intramedulla nail untuk menstabilkan tulang (Cluett, 2008). Fiksasi interna dilaksanakan dalam rangka memperbaiki fungsi dengan mengembalikan gerakan, stabilitas, disabilitas dan mengurangi nyeri. Akibat adanya fraktur mengakibatkan terjadinya keterbatasan gerak, terutama di daerah sendi yang fraktur dan sendi yang ada di daerah sekitarnya. Karena keterbatasan gerak tersebut mengakibatkan terjadinya keterbatasan lingkup gerak sendi dan mengakibatkan terjadinya gangguan pada fleksibilitas sendi.

Fleksibilitas sendi adalah luas bidang gerak yang maksimal pada persendian, tanpa dipengaruhi oleh suatu paksaan atau tekanan (Fatmah, 2010). Terjadinya gangguan fleksibilitas sendi akibat suatu keadaan antara lain kelainan postur, gangguan perkembangan otot, kerusakan system saraf pusat, dan trauma langsung pada system musculoskeletal, misalnya fraktur yang menimbulkan respon nyeri pada daerah yang sakit (Potter \& Perry, 2005). Dari hasil penelitian Yandri (2011), ditemukan 3 kasus $(15 \%)$ dari 20 orang pasien fraktur femur terpasang fiksasi interna mengalami gangguan fleksibilitas sendi lutut. Adapun pencegahan yang dapat dilakukan adalah dengan cara melakukan mobilisasi dini. 
Mobilisasi adalah kemampuan untuk bergerak dengan bebas mudah, berirama, terarah di lingkungan dan merupakan bagian yang sangat penting dalam kehidupan (Kozier dkk, 2010). Mobilisasi mengacu pada kemampuan seseorang untuk bergerak dengan bebas, berfokus pada rentang gerak, gaya berjalan, latihan, toleransi aktifitas dan kesejajaran tubuh (Potter \& Perry, 2006). Menurut Doherty (2006), pada pasien pasca operasi memerlukan perubahan posisi kecuali melakukannya merupakan kontraindikasi, posisi pasien diubah setiap 30 menit dari sisi ke sisi sampai sadar dan kemudian dilakukan mobilisasi dini 8-12 jam pertama. Menurut hasil wawancara dengan 2 orang dokter residen bedah mobilisasi sebaiknya dilakukan sedini mungkin, sedangkan wawancara dengan ahli fisioterapis dapat dilaksanakan bila tandatanda dari peradangan tidak ada dan dapat dilaksanakan 24 jam pasca operasi.

Rentang gerak (Range of Motion) adalah pergerakan maksimal yang mungkin dilakukan oleh sendi tersebut (Kozier dkk, 2010). Rentang gerak merupakan jumlah maksimum gerakan yang mungkin dilakukan sendi pada salah satu dari tiga potongan tubuh: sagital, frontal, dan transversal (Potter \& Perry, 2005). Untuk mempertahankan dan meningkatkan gerakan sendi, latihan rentang gerak harus dimulai segera mungkin setelah pembedahan, lebih baik dalam 24 jam pertama dan dilakukan di bawah pengawasan untuk memastikan bahwa mobilisasi dilakukan dengan tepat serta dengan cara yang aman (Smeltzer \& Bare, 2002), tapi ini belum berjalan dengan semestinya. Hal ini disebabkan karena adanya perasaan nyeri akibat dari tindakan pembedahan yang dilakukan. Dari hasil penelitian yang dilakukan oleh Astuti (2006), setelah dilakukan rentang gerak aktif pada pasien post operasi fraktur femur $1 / 3$ medial dextra dengan pemasangan plate dan screw, sebanyak 6 kali latihan didapatkan hasil nyeri berkurang, rentang gerak panggul kanan aktif dan pasif, kekuatan otot meningkat, oedema berkurang dan aktifitas fungsional meningkat dan dapat dievaluasi bahwa pasien dalam melakukan aktifitas sehari-hari sudah dapat berjalan sendiri, biarpun masih dibantu dengan kruk. Dari pengalaman peneliti selama bertugas di ruang Bedah RSUP Dr. M. Djamil Padang sejak tahun 1989-2007, pelaksanaan latihan rentang gerak pada pasien fraktur femur terpasang fiksasi interna belum terlaksana dengan baik. Standar Operasional Prosedur juga belum tersedia diruangan. Ini diketahui dari hasil wawancara dengan SPF dan beberapa orang Kepala Ruangan. Advis dokter mengenai mobilisasi ada ditemukan, tapi belum terlaksana dengan baik. Penyuluhan rentang gerak ada dilakukan, namun tindak lanjut dan evaluasinya tidak berjalan sesuai yang diharapkan.

Berdasarkan hasil studi pendahuluan yang dilakukan peneliti pada tanggal 18 Oktober 2012 sampai dengan 27 Oktober 2012 di Ruang Rawat Inap Trauma Centre, dari empat orang pasien dengan fraktur femur terpasang fiksasi interna didapatkan tiga orang klien mengalami gangguan fleksibilitas sendi lutut dengan fleksi kurang dari $70^{\circ}$. Hasil wawancara dengan pasien didapat keluhan pasien merasa takut melakukan latihan rentang gerak karena sakit dan juga tidak adanya penyuluhan mengenai manfaat dilakukan latihan rentang gerak. Ini dapat dilihat dari perilaku perawat yang belum melaksanakan latihan rentang gerak pada pasien pasca operasi fraktur terpasang fiksasi interna. Akibat keterlambatan dalam pendeteksian, mengakibatkan terjadinya gangguan fleksibilitas sendi, yang akhirnya pasien dirujuk ke fisioterapi.
A. Penetapan Masalah
Oleh sebab itu peneliti merumuskan masalah penelitian apakah 
ada pengaruh pemberian latihan rentang gerak terhadap fleksibilitas sendi anggota gerak bawah pada pasien fraktur femur terpasang fiksasi interna di Ruang Trauma Centre RSUP Dr. M. Djamil Padang.

C. Tujuan Penelitian

1. Tujuan Umum

Diketahui pengaruh pemberian latihan rentang gerak terhadap fleksibilitas sendi anggota gerak bawah pada pasien fraktur femur terpasang fiksasi interna di Ruang Trauma Centre RSUP Dr. M. Djamil Padang.

2. Tujuan Khusus

a. Diidentifikasi fleksibilitas sendi anggota gerak bawah yang meliputi fleksibilitas fleksi sendi panggul, fleksi sendi lutut, dorsofleksi dan plantarfleksi pergelangan kaki pada pasien fraktur femur terpasang fiksasi interna setelah diberi latihan rentang gerak di ruang rawat Trauma Centre RSUP Dr. M. Djamil Padang.

b. Diidentifikasi fleksibilitas sendi anggota gerak bawah yang meliputi fleksibilitas fleksi sendi panggul, fleksi sendi lutut, dorsofleksi dan plantarfleksi pergelangan kaki pada pasien fraktur femur terpasang fiksasi interna yang bergerak tidak sesuai aturan penelitian di ruang rawat Trauma Centre RSUP Dr. M. Djamil Padang.

c. Diidentifikasi perbedaan fleksibilitas sendi anggota gerak bawah yang meliputi fleksibilitas fleksi sendi panggul, fleksi sendi lutut, dorsofleksi dan plantarfleksi pergelangan kaki sesudah diberi latihan rentang gerak dan yang bergerak tidak sesuai aturan penelitian pada pasien fraktur femur terpasang fiksasi interna di ruang rawat Trauma Centre RSUP Dr. M. Djamil Padang.

D. Manfaat Penelitian

1. Bagi Pelayanan Keperawatan Penelitian ini diharapkan menjadi bahan intervensi yang spesifik dalam konteks asuhan keperawatan pada pasien dengan fraktur ekstremitas bawah dengan mendesiminasikan dan mensosialisasikan kepada pemegang kebijakan serta perawat pelaksana untuk dijadikan acuan guna meningkatkan mutu pelayanan keperawatan khusunya untuk mencegah terjadinya masalah gangguan fleksibilitas sendi.

2. Bagi Institusi Rumah Sakit

Hasil penelitian ini diharapkan memberikan masukan dan bahan pertimbangan dalam penyusunan dan pembuatan standar operasional prosedur (SOP) latihan rentang gerak untuk mencegah terjadinya masalah gangguan fleksibilitas sendi.

3. Bagi Penelitian Selanjutnya

Penelitian ini diharapkan dapat menjadi rujukan dan data dasar bagi penelitian berikutnya terutama yang terkait dengan pengaruh pemberian latihan rentang gerak terhadap fleksibilitas sendi anggota gerak bawah pada pasien fraktur femur.

A. Jenis dan Desain Penelitian

Penelitian ini adalah penelitian kuantitatif dengan menggunakan desain Quasy Eksperiment dengan pendekatan Posttest Only Control Group Design (Notoatmojo, 2010). Pada kelompok eksperimen latihan rentang gerak 
dimulai pada hari kedua pasca operasi. Latihan rentang gerak dilakukan selama 3 hari dengan durasi 15 menit, dengan 5 kali pengulangan setiap sendi dengan sesi 2 kali sehari pagi dan sore hari. Rentang gerak diukur tingkat fleksibilitas sendinya (posttest), pada hari kelima post operasi, sedangkan pada kelompok control, penatalaksanaan rentang gerak dimulai pada hari kedua pasca operasi, dilakukan selama 3 hari dengan durasi 15 menit, dengan 5 kali pengulangan setiap sendi dengan sesi 2 kali sehari pagi dan sore hari ada dianjurkan, tapi dalam penatalaksanaannya latihan rentang gerakdilakukan tidak sesuai aturan penelitian. Pengukuran fleksibilitas sendi (posttest) tetap dilakukan. sama dengan kelompok eksperimen, yaitu hari kelima post operasi.

Rancangan penelitian ini adalah sebagai berikut:

\begin{tabular}{|c|c|c|}
\hline Subjek & Intervensi & Posttest \\
\hline Kelompok Eksperimen & X1 & O1 (E) \\
\hline Kelompok Kontrol & X2 & O2 (P) \\
\hline
\end{tabular}

Keterangan:

$\begin{array}{ll}\text { KE } & \text { : Kelompok Eksperimen } \\ \text { X1 } & : \text { Pemberian latihan rentang gerak } \\ \text { O1 }(\text { E) } & : \text { Pengukuran nilai fleksibilitas sendi kelompok eksperimen } \\ \text { KP } & : \text { Kelompok control } \\ \text { X2 } & : \text { Melakukan latihan rentang gerak tidak sesuai dengan aturan penelitian } \\ \text { O2 }(P) & : \text { Pengukuran nilai fleksibilitas sendi kelompok kontrol. }\end{array}$

B. Populasi dan Sampel Penelitian

1. Populasi Penelitian

Populasi adalah

keseluruhan objek penelitian atau objek yang akan diteliti (Notoatmodjo, 2010). Populasi dalam penelitian ini adalah seluruh pasien fraktur femur yang terpasang fiksasi interna di ruang rawat inap Trauma Centre RSUP Dr. M. Djamil Padang selama bulan Oktober 2012 sampai dengan Desember 2013 dengan rata-rata perbulan 10 - 15 orang pasien.

2. Sampel Penelitian
Sampel adalah bagian dari populasi yang diambil dari keseluruhan objek yang diteliti dan dianggap mewakili seluruh populasi (Notoatmodjo, 2010). Sampel yang digunakan dalam penelitian ini adalah klien dengan fraktur femur terpasang fiksasi interna dan memenuhi kriteria inklusi.

Teknik sampling yang digunakan dalam penelitian ini adalah Non Probability Sampling yaitu Purposive Sampling. Purposive Sampling adalah teknik penetapan sampel berdasarkan pertimbangan tertentu yang 
dibuat oleh peneliti sendiri berdasarkan ciri-ciri atau sifatsifat populasi yang sudah diketahui sebelumnya (Notoatmodjo, 2010). Jumlah sampel yang ditetapkan menurut Sugiyono (2010) untuk penelitan eksperimen sederhana adalah antara 10 sampai 20 sampel. Pada penelitian ini jumlah sampel yang telah diambil adalah 10 orang kelompok eksperimen dan 10 orang kelompok kontrol.

3. Kriteria Sampel

a. Kriteria Inklusi

1) Bersedia menjadi responden dan diberi perlakuan latihan rentang gerak dan yang melakukan latihan rentang gerak tidak sesuai aturan penelitian.

2) Dapat berkomunikasi dengan baik.

3) Pasien pasca operasi fraktur femur terpasang fiksasi interna lebih dari 48 jam.

4) Pasien yang belum melakukan latihan rentang gerak.

5) Pasien tidak ada menderita penyakit system musculoskeletal seperti tumor tulang.

6) Pasien tidak ada menderita penyakit neurologis

7) Pasien berumur 15-45 tahun.

b. Kriteria Eklusi

1) Pasien pulang sebelum terapi selesai dilakukan.

2) Pasien terpasang traksi.

C. Tempat dan Waktu Penelitian
Penelitian ini dilaksanakan di ruang rawat inap Trauma Centre RSUP Dr. M. Djamil Padang. Waktu penelitian dilaksanakan pada bulan Oktober 2012 - Mei 2013, dan pengumpulan data telah dilaksanakan pada 16 Maret 2013 13 April 2013.

D. Variabel dan Defenisi Operasional

1. Variabel Penelitian

a. Variabel bebas atau variabel independen yaitu veriabel yang mempengaruhi. Variabel independen dalam penelitian ini adalah pemberian latihan rentang gerak.

b. Variabel terikat/dependen yaitu yang dipengaruhi. Variabel terikat dalam penelitian ini adalah fleksibilitas sendi.

E. Instrumen Penelitian

Instrumen penelitian yang dipakai adalah Goniometer yang digunakan dalam pengukuran sendi pasien yang mengalami fraktur femur terpasang fiksasi interna yang telah dilakukan latihan rentang gerak dan yang bergerak tidak sesuai aturan penelitian.

1) Latihan gerak dilakukan dengan durasi 15 menit, dengan 55 kali pengulangan setiap sendi dengan sesi 2 kali sehari pagi dan sore hari.

F. Teknik Analisa Data

1. Analisa Univariat

Analisis univariat dilakukan untuk menjelaskan karakteristik masing-masing variabel yang diteliti. Variabel yang dianalisis dalam penelitian ini adalah umur, jenis kelamin, 
diagnosa medis dan gambaran fleksibilitas sendi panggul, lutut, dan pergelangan kaki pada pasien fraktur femur terpasang fiksasi interna. Penyajian data kategorik seperti umur, jenis kelamin, dan diagnosa medis menggunakan persentase atau proporsi. Kategori umur menurut Depkes RI, (2009) adalah 15-25 tahun (masa remaja akhir, 26-35 tahun (masa dewasa awal), dan 36-45 tahun (masa dewasa akhir). Sedangkan diagnosa medis meliputi fraktur femur 1/3 proximal, tengah dan distal. Penyajian data numerik seperti gambaran fleksibilitas sendi panggul, lutut, dan pergelangan kaki menggunakan nilai mean, standar deviasi, minimum, dan maksimum.

2. Analisa Bivariat

Analisis bivariat dilakukan untuk membuktikan hipotesis penelitian yaitu pemberian latihan rentang gerak berpengaruh terhadap fleksibilitas sendi anggota gerak bawah pada pasien fraktur femur terpasang fiksasi interna. Sebelum menentukan jenis analisis bivariat yang digunakan, terlebih dahulu dilakukan uji normalitas untuk jenis data numerik dengan Shapiro Wilk.

Data numerik sebagai hasil penelitian umumnya mengikuti distribusi normal, namun tidak mustahil sekumpulan data numerik tidak mengikuti asumsi distribusi normal, oleh karena itu untuk mengetahuinya dilakukan uji normalitas. Uji statistik untuk seluruh analisis tersebut diatas dianalisis dengan tingkat kemaknaan $95 \%$ (alpha $0.05 \%$ ).

Uji statistik non parametrik yang digunakan untuk menguji perbedaan mean antara dua kelompok yang independen memakai uji Mann Whitney.

\section{HASIL PENELITIAN}

\section{A. Gambaran Umum Penelitian}

Penelitian dilakukan terhadap pasien fraktur femur terpasang fiksasi interna yang dirawat di ruang rawat Trauma Centre RSUP Dr. M. Djamil Padang dari tanggal 16 Maret 2013 sampai dengan 13 April 2013 dengan jumlah responden 20 orang yang memenuhi kriteria sampel yang telah ditentukan. Responden dibagi menjadi dua kelompok, yaitu 10 responden dijadikan kelompok eksperimen yang diberikan latihan rentang gerak dan 10 responden dijadikan kelompok kontrol yang melakukan latihan rentang gerak tidak sesuai aturan penelitian.

Responden adalah pasien fraktur femur terpasang fiksasi interna yang dirawat di ruang rawat inap Trauma Centre RSUP Dr. M. Djamil Padang Tahun 2013. Selanjutnya ditampilkan data karakteristik pasien berdasarkan umur, jenis kelamin, dan diagnosa medik. 
Tabel 3 Distribusi Frekuensi Pasien Berdasarkan Karakteristik Umur, Jenis Kelamin dan Diagnosis Medis pada Kedua Kelompok Pasien Di Ruang Rawat Trauma Centre RSUP Dr.M.Djamil Padang Tahun 2013

\begin{tabular}{|c|c|c|c|c|c|c|}
\hline \multirow[t]{2}{*}{ No } & \multirow[t]{2}{*}{ Karakteritik } & \multirow[t]{2}{*}{ Kriteria } & \multicolumn{2}{|c|}{$\begin{array}{c}\text { Kelompok } \\
\text { Eksperimen }\end{array}$} & \multicolumn{2}{|c|}{$\begin{array}{c}\text { Kelompok } \\
\text { Kontrol }\end{array}$} \\
\hline & & & f & $\%$ & $\mathbf{F}$ & $\%$ \\
\hline \multirow[t]{4}{*}{1} & Umur & 15-25 tahun & 5 & 50 & 4 & 40 \\
\hline & & 26-35 tahun & 2 & 20 & 1 & 10 \\
\hline & & $36-45$ tahun & 3 & 30 & 5 & 50 \\
\hline & Jumlah & & 10 & 100 & 10 & 100 \\
\hline \multirow[t]{3}{*}{2} & Jenis Kelamin & Laki-laki & 7 & 70 & 7 & 70 \\
\hline & & Perempuan & 3 & 30 & 3 & 30 \\
\hline & Jumlah & & 10 & 100 & 10 & 100 \\
\hline \multirow[t]{4}{*}{3} & Diagnosa & Fraktur Femur 1/3 Distal & 2 & 20 & 3 & 30 \\
\hline & Medik & Fraktur Femur 1/3 Tengah & 6 & 60 & 4 & 40 \\
\hline & & Fraktur Femur 1/3 Proksimal & 2 & 20 & 3 & 30 \\
\hline & Jumlah & & 10 & 100 & 10 & 100 \\
\hline
\end{tabular}

Berdasarkan tabel 3, memperlihatkan karakteristik dari 20 orang pasien penelitian yang terdiri dari 10 orang pasien kelompok yang diberikan latihan rentang gerak dan 10 orang pasien yang melakukan latihan rentang gerak tidak sesuai dengan aturan penelitian. Proporsi pasien berdasarkan usia, pada kelompok eksperimen separuh pasien $(50 \%)$ dengan kelompok usia 1525 tahun, sedangkan pada kelompok kontrol separuh pasien (50 \%) berada pada kelompok usia 36-45 tahun. Proporsi pasien dilihat dari jenis kelamin pada kedua kelompok adalah sama yaitu $70 \%$ pasien berjenis kelamin laki-laki. Terakhir, proporsi pasien dilihat dari diagnosa medik, pada kelompok eksperimen lebih dari seperuh pasien 60 $\%$ dengan diagnosa fraktur femur $1 / 3$ tengah, begitu juga dengan kelompok kontrol hampir separuh pasien $40 \%$ dengan diagnosa medik fraktur femur $1 / 3$ tengah.

\section{B. Analisa Univariat}


Tabel 4 Gambaran Fleksibilitas Sendi Panggul, Lutut dan Pergelangan Kaki pada Pasien Fraktur Femur Terpasang Fiksasi Interna yang Mendapatkan Latihan Rentang Gerak di Ruang Rawat Trauma Center RSUP Dr. M. Djamil Padang Tahun 2013

\begin{tabular}{|c|c|c|c|c|}
\hline \multirow[b]{3}{*}{ NO } & \multicolumn{4}{|c|}{ Kelompok Eksperimen } \\
\hline & \multirow{2}{*}{$\begin{array}{c}\text { Panggul } \\
\text { Derajat } \\
\text { Fleksi }\end{array}$} & \multirow{2}{*}{$\begin{array}{c}\text { Lutut } \\
\text { Derajat } \\
\text { Fleksi }\end{array}$} & \multicolumn{2}{|c|}{ Pergelangan Kaki } \\
\hline & & & $\begin{array}{c}\text { Derajat } \\
\text { Dorsofleksi }\end{array}$ & $\begin{array}{c}\text { Derajat } \\
\text { Plantarfleksi }\end{array}$ \\
\hline 1 & 60 & 65 & 15 & 45 \\
\hline 2 & 75 & 50 & 20 & 50 \\
\hline 3 & 75 & 65 & 10 & 45 \\
\hline 4 & 60 & 70 & 15 & 45 \\
\hline 5 & 80 & 60 & 10 & 45 \\
\hline 6 & 60 & 60 & 10 & 50 \\
\hline 7 & 75 & 70 & 15 & 45 \\
\hline 8 & 65 & 70 & 15 & 45 \\
\hline 9 & 75 & 50 & 10 & 50 \\
\hline 10 & 60 & 50 & 5 & 50 \\
\hline Minimum & 60 & 50 & 5 & 45 \\
\hline Maximum & 80 & 70 & 20 & 50 \\
\hline Mean & 68.5 & 61 & 12.5 & 47.0 \\
\hline $\begin{array}{c}\text { Std. } \\
\text { deviation }\end{array}$ & 8.18 & 8.43 & 4.25 & 2.58 \\
\hline
\end{tabular}

Berdasarkan tabel 4, rata-rata fleksibilitas fleksi sendi panggul adalah 68.5 derajat dengan rentang tertinggi adalah 80 derajat dan terendah adalah 60 derajat. Rata-rata fleksibilitas fleksi sendi lutut adalah 61 derajat dengan rentang tertinggi 70 derajat dan terendah
50 derajat. Rata-rata fleksibilitas dorsofleksi adalah 12.5 derajat dengan rentang tertinggi 20 dan terendah 5 derajat, sedangkan rata-rata fleksisibilitas plantarfleksi adalah 47.0 derajat dengan rentang tertinggi 50 derajat dan terendah 45 derajat.

Tabel 5 Gambaran Fleksibilitas Sendi Panggul, Lutut dan Pergelangan Kaki pada Pasien Fraktur Femur Terpasang Fiksasi Interna yang Melakukan Latihan Rentang Gerak Tidak Sesuai Dengan Aturan Penelitian di Ruang Rawat Trauma Center RSUP Dr. M. Djamil Padang Tahun 2013

\begin{tabular}{|l|c|c|c|}
\hline \multirow{2}{*}{ No } & \multicolumn{3}{|c|}{ Kelompok Kontrol } \\
\cline { 2 - 4 } & Panggul & Lutut & Pergelangan Kaki \\
\hline
\end{tabular}




\begin{tabular}{|c|c|c|c|c|}
\hline & $\begin{array}{c}\text { Derajat } \\
\text { Fleksi }\end{array}$ & $\begin{array}{c}\text { Derajat } \\
\text { Fleksi }\end{array}$ & $\begin{array}{c}\text { Derajat } \\
\text { Dorsofleksi }\end{array}$ & $\begin{array}{c}\text { Derajat } \\
\text { Plantarfleksi }\end{array}$ \\
\hline 1 & 45 & 15 & 0 & 35 \\
\hline 2 & 40 & 20 & 5 & 30 \\
\hline 3 & 50 & 20 & 0 & 45 \\
\hline 4 & 50 & 10 & 0 & 30 \\
\hline 5 & 45 & 15 & 0 & 25 \\
\hline s6 & 45 & 20 & 5 & 30 \\
\hline 7 & 50 & 20 & 0 & 30 \\
\hline 8 & 50 & 15 & 5 & 45 \\
\hline 9 & 40 & 10 & 0 & 35 \\
\hline 10 & 40 & 10 & 0 & 25 \\
\hline $\begin{array}{l}\text { Minimum } \\
\text { Maximum }\end{array}$ & 40 & 10 & 0 & 45 \\
Mean & 45.5 & 15.50 & $\mathbf{5}$ & $\mathbf{3 3 . 5}$ \\
Std. & 4.4 & 4.3 & 2.4 & 6.7 \\
deviation & & & & \\
\hline
\end{tabular}

Berdasarkan tabel 5, rata-rata fleksibilitas fleksi sendi panggul adalah 45.5 derajat dengan rentang tertinggi adalah 50 derajat dan terendah adalah 40 derajat. Rata-rata fleksibilitas fleksi sendi lutut adalah 15.5 dengan rentang tertinggi 20 derajat dan terendah 10

\section{Analisa Bivariat}

Sebelum analisa bivariat, dilakukan uji normalitas untuk menentukan uji yang akan dilakukan baik pada kelompok eksperimen yang diberikan latihan rentang gerak, maupun pada kelompok kontrol yang melakukan latihan rentang gerak tidak sesuai dengan aturan penelitian.

1. Hasil uji normalitas pada tabel Shapiro-Wilk untuk variabel fleksibilitas fleksi sendi panggul, didapatkan pada kelompok eksperimen nilai $p=0.012$ sedangkan pada kelompok kontrol nilai $p=0.017$ karena kedua kelompok mempunyai kemaknaan derajat. Dan rata-rata fleksibilitas dorsofleksi adalah 1.5 derajat dengan rentang tertinggi 5 dan terendah 0 derajat, sedangkan rata-rata fleksibilitas plantarfleksi adalah 33.5 derajat dengan rentang tertinggi 45 derajat dan terendah 25 derajat.

$<0.05$ dapat disimpulkan data berdistribusi tidak normal, maka uji non parametrik yang digunakan adalah uji Mann Whitney.

2. Hasil uji normalitas pada tabel Shapiro-Wilk untuk variabel fleksibilitas fleksi sendi lutut pada kelompok eksperimen nilai $p=$ 0.041 sedangkan pada kelompok kontrol nilai $p=0.017$ karena kedua kelompok mempunyai kemaknaan $<0.05$ dapat disimpulkan data berdistribusi tidak normal, maka uji non parametrik yang digunakan adalah uji Mann Whitney. 
3. Hasil uji normalitas pada tabel Shapiro-Wilk untuk variabel fleksibilitas dorsofleksi pada kelompok eksperimen nilai $p=$ 0.258 sedangkan pada kelompok kontrol nilai $p=0.000$ karena salah satu nilai mempunyai kemaknaan $<0.05$ dapat disimpulkan data berdistribusi tidak normal, maka uji parametrik yang digunakan adalah uji Mann Whitney.
4. Hasil uji normalitas pada tabel Shapiro-Wilk untuk variabel fleksibilitas plantarfleksi pada kelompok eksperimen nilai $p=$ 0.000 sedangkan pada kelompok kontrol nilai $p=0.021$ karena kedua kelompok mempunyai kemaknaan $<0.05$ dapat disimpulkan data berdistribusi tidak normal, maka uji non parametrik yang digunakan adalah uji Mann Whitney.

Tabel 6 Analisis Perbedaan Fleksibilitas Fleksi Sendi Panggul Pasien pada Kelompok Eksperimen yang diberikan Latihan Rentang Gerak dan pada Kelompok Kontrol yang Melakukan Latihan Rentang Gerak tidak Sesuai Aturan Penelitian Pada Pasien Fraktur Femur Di Ruang Rawat Trauma Center RSUP Dr. M. Djamil Padang Tahun 2013

\begin{tabular}{|c|c|c|c|c|c|}
\hline & $\begin{array}{c}\text { Kelompok } \\
\text { Responden }\end{array}$ & $\mathrm{N}$ & Mean Rank & $\mathrm{Z}$ & $\mathrm{p}$ value \\
\hline $\begin{array}{c}\text { Fleksibilitas } \\
\text { Fleksi Sendi } \\
\text { Panggul }\end{array}$ & Eksperimen & 10 & 15.5 & \multirow{2}{*}{-3.84} & 0,000 \\
\cline { 2 - 6 } & Variabel & 10 & 5.5 & & \\
\hline
\end{tabular}

Hasil analisis data didapatkan ratarata rentang gerak fleksi sendi panggul pada kelompok eksperimen adalah 15.5 derajat, sedangkan pada kelompok kontrol adalah 5.5 derajat. Hasil uji statistic Mann Whitney dapat disimpulkan ada perbedaan yang signifikan rentang gerak fleksi panggul antara kelompok eksperimen yang diberikan latihan rentang gerak dan kelompok kontrol yang melakukan latihan rentang gerak tidak sesuai aturan penelitian $(p$ value $=0.000<$ $0.05)$.

Tabel 7 Analisis Perbedaan Fleksibilitas Fleksi Sendi Lutut Pasien pada Kelompok Eksperimen yang diberikan Latihan Rentang Gerak Sendi dan pada Kelompok Kontrol yang Melakukan Latihan Rentang Gerak tidak Sesuai Aturan Penelitian Pada Pasien Fraktur Femur Di Ruang Rawat Trauma Center RSUP Dr. M. Djamil Padang Tahun 2013

\begin{tabular}{|l|c|c|c|c|c|}
\hline \multicolumn{1}{|c|}{ Variabel } & $\begin{array}{c}\text { Kelompok } \\
\text { Responden }\end{array}$ & $\mathrm{N}$ & $\begin{array}{c}\text { Mean } \\
\text { Rank }\end{array}$ & $\mathrm{Z}$ & $\mathrm{p}$ value \\
\hline $\begin{array}{l}\text { Fleksibilitas } \\
\text { Fleksi Sendi } \\
\text { Lutut }\end{array}$ & Eksperimen & 10 & 15.5 & \multirow{2}{*}{-3.82} & 0,000 \\
\cline { 2 - 6 } & Kontrol & 10 & 5.5 & & \\
\hline
\end{tabular}


Hasil analisis data didapatkan ratarata rentang gerak fleksi lutut pada kelompok eksperimen adalah 15.5 derajat, sedangkan pada kelompok kontrol adalah 5.5 derajat. Hasil uji statistik Mann Whitney dapat disimpulkan ada perbedaan yang signifikan rentang gerak fleksi lutut antara kelompok eksperimen yang diberikan latihan rentang gerak dan kelompok kontrol yang melakukan latihan rentang gerak tidak sesuai aturan penelitian ( $p$ value $=0.000$ $<0.05$ ).

Tabel 8 Analisis Perbedaan Fleksibilitas Dorsofleksi Pergelangan Kaki Pasien pada Kelompok Eksperimen yang diberikan Latihan Rentang Gerak dan pada Kelompok Kontrol yang Melakukan Latihan Rentang Gerak tidak Sesuai Aturan Penelitian Pada Pasien Fraktur Femur Di Ruang Rawat Trauma Center RSUP Dr. M. Djamil Padang Tahun 2013

\begin{tabular}{|l|c|c|c|c|c|}
\hline \multicolumn{1}{|c|}{ Variabel } & $\begin{array}{c}\text { Kelompok } \\
\text { Responden }\end{array}$ & $\mathrm{N}$ & $\begin{array}{c}\text { Mean } \\
\text { Rank }\end{array}$ & $\mathrm{Z}$ & $\mathrm{p}$ value \\
\hline $\begin{array}{l}\text { Fleksibilitas } \\
\text { Dorsofleksi } \\
\text { Pergelangan Kaki }\end{array}$ & Eksperimen & 10 & 15.35 & \multirow{2}{*}{-3.791} & 0,000 \\
\cline { 2 - 5 } & Kontrol & 10 & 5.65 & \\
\hline
\end{tabular}

Hasil analisis data didapatkan ratarata rentang gerak dorsofleksi pada kelompok eksperimen adalah 15,35 derajat, sedangkan pada kelompok kontrol adalah 5.65. Hasil uji statistic Mann Whitney dapat disimpulkan ada perbedaan yang signifikan rentang gerak dorsofleksi antara kelompok eksperimen dan kelompok control $(p$ value $=0.000<0.05$ ).

Tabel 9 Analisis Perbedaan Fleksibilitas Plantarfleksi Pergelangan Kaki Pasien pada Kelompok Eksperimen yang diberikan Latihan Rentang Gerak dan pada Kelompok Kontrol yang Melakukan Latihan Rentang Gerak tidak Sesuai Aturan Penelitian Pada Pasien Fraktur Femur Di Ruang Rawat Trauma Center RSUP Dr. M. Djamil Padang Tahun 2013

\begin{tabular}{|l|c|c|c|c|c|}
\hline \multicolumn{1}{|c|}{ Variabel } & $\begin{array}{c}\text { Kelompok } \\
\text { Responden }\end{array}$ & $\mathrm{N}$ & $\begin{array}{c}\text { Mean } \\
\text { Rank }\end{array}$ & $\mathrm{Z}$ & $\mathrm{p}$ value \\
\cline { 1 - 5 } $\begin{array}{l}\text { Fleksibilitas } \\
\text { Plantarfleksi } \\
\text { P'gelangan Kaki }\end{array}$ & Eksperimen & 10 & 14.9 & \multirow{2}{*}{-3.48} & 0,000 \\
\cline { 2 - 5 } & Kontrol & 10 & 6.10 & \\
\hline
\end{tabular}

Hasil analisis data didapatkan ratarata rentang gerak plantarfleksi pada kelompok eksperimen adalah 14.9 derajat, sedangkan pada kelompok kontrol adalah
6.1. Hasil uji statistic Mann Whitney dapat disimpulkan ada perbedaan yang signifikan rentang gerak plantarfleksi antara kelompok 
Ners Jurnal Keperawatan Volume 10. No 1, Oktober 2014 : 176 - 196

eksperimen dan kelompok kontrol ( $p \quad$ value $=0.000<0.05)$.

\section{PEMBAHASAN}

\section{A. Fleksibilitas Sendi Pada Pasien Fraktur Femur Terpasang Fiksasi Interna Setelah Pemberian Latihan Rentang Gerak (Kelompok Eksperimen)}

Berdasarkan hasil analisis penelitian dari 10 orang pasien kelompok eksperimen, didapatkan hasil dari fleksi sendi panggul dengan nilai maximum 80 derajat dan minimum 60 derajat, pada fleksi sendi lutut di dapatkan nilai maximum 70 derajat dan minimum 50 derajat. Selanjutnya dorsofleksi sendi pergelangan kaki didapatkan nilai maximum 20 derajat dan minimum 5 derajat. Sedangkan untuk plantarfleksi sendi pergelangan kaki di dapat nilai maximum 50 derajat dan minimum 45 derajat.

Berdasarkan teori yang dikemukakan oleh Potter dan Perry (2005), rentang normal fleksi sendi panggul adalah 90- 120 derajat, jika dibandingkan dengan hasil yang didapat ada peningkatan nilai yang signifikan dan mendekati nilai normal. Pada sendi lutut di dapatkan rentang normal 120-130 derajat dan dibandingkan dengan hasil latihan yang diberikan pada sendi lutut terdapat peningkatan, walaupun sebahagian. Selanjutnya, dorsofleksi pergelangan kaki dengan rentang normal 20-30 derajat dibandingkan hasil yang didapat lebih dari separuh pasien mendekati normal, sedangkan untuk plantarfleksi dengan rentang normal 45-50 derajat didapat peningkatan nilai yang sangat signifikan.

Hasil penelitian menunjukkan bahwa setelah diberikan latihan rentang gerak selama 3 hari dengan frekuensi 2 kali sehari selama 15 menit menunjukkan hasil yang memuaskan dalam mengatasi gangguan fleksibilitas sendi. Hasil penelitian ini berkorelasi dengan penelitian yang dilakukan oleh Astuti (2006), setelah dilakukan rentang gerak aktif pada pasien post operasi fraktur femur $1 / 3$ medial dextra dengan pemasangan plate dan screw, sebanyak 6 kali latihan didapatkan hasil, rentang gerak panggul kanan aktif dan pasif, kekuatan otot meningkat, nyeri berkurang, oedema berkurang dan aktifitas fungsional meningkat dan dapat dievaluasi bahwa pasien dalam melakukan aktifitas sehari-hari sudah dapat berjalan sendiri, walaupu masih dibantu dengan kruk.

Hasil penelitian Astuti (2006) ini juga perkuat oleh Werner (2009) yang menyatakan bahwa latihan rentang gerak yang dilakukan secara teratur dapat meningkatkan kekuatan otot pada klien yang mengalami gangguan atau keterbatasan fungsi motorik. Latihan rentang gerak yang dilakukan secara kontinyu sepanjang hidup dapat mempertahankan fungsi sendi serta mencegah terjadinya gangguan fleksibilitas dan deformitas. 
Nilai fleksibilitas sendi pada kelompok eksperimen yang diberikan latihan rentang gerak menunjukkan dari keempat nilai fleksibilitas sendi (sendi panggul, lutut dorsofleksi dan plantarfleksi pergelangan kaki), fleksibilitas sendi lutut mendapat hasil yang kurang memuaskan. Hal ini dapat disebabkan oleh adanya trauma langsung pada system musculoskeletal yang menyebabkan terjadinya fraktur, dan adanya perasaan nyeri akibat adanya incisi (luka operasi) di daerah paha tempat fraktur terjadi. Setelah pembedahan nyeri mungkin sangat berat, edema, hematom, dan spasme otot, sehingga hal ini dapat berdampak terjadinya gangguan pada kontraksi dan relaksasi otot. Otot-otot yang penting dalam kontraksi dan relaksasi, bila tidak digerakkan mengakibatkan salah satunya adalah gangguan fleksibilitas sendi (Potter \& Perry, 2005). Selain itu gangguan fleksibilitas juga dipengaruhi akibat adanya masa inflamasi dalam proses penyembuhan luka yang berlangsung selama 2-3 hari pasca operasi (Smeltzer \& Bare, 2002).

Setelah pembedahan nyeri mungkin sangat berat, adanya edema, hematom dan spasme otot sehingga hal ini dapat berdampak terjadinya gangguan pada kontraksi dan relaksasi otot. Otot-otot yang penting dalam kontraksi dan relaksasi, bila tidak digerakkan mengakibatkan salah satunya adalah gangguan fleksibilitas sendi (Potter \& Perry, 2005).

Dilihat dari karakteristik pasien pada kelompok eksperimen berdasarkan jenis kelamin lebih dari lebih separuh pasien (70\%) adalah laki-laki. Berdasarkan hasil penelitian yang dilakukan oleh Phillips (1955), Kirchner dan Glines (1957), dalam Bloomfield, dkk (1994:212), jenis kelamin berpengaruh juga terhadap fleksibilitas sendi seseorang. Wanita lebih lentur daripada lakilaki karena tulang-tulangnya lebih kecil dan otot-ototnya lebih sedikit daripada laki-laki.
Menurut teori yang dikemukakan oleh Tseng dkk (2007) dan Smeltzer dan Bare (2002), latihan rentang gerak bertujuan untuk mempertahankan fleksibilitas dan mobilitas sendi, mengembalikan kontrol motorik, meningkatkan/ mempertahankan integritas sendi dan jaringan lunak, membantu sirkulasi dan nutrisi sinovial dan menurunkan pembentukan kontraktur terutama pada ekstremitas yang mengalami paralisis. Manfaat lain yang didapatkan dari latihan rentang gerak yaitu dapat memaksimalkan fungsi aktifitas kehidupan sehari-hari, mengurangi atau menghambat nyeri, mencegah bertambah buruknya sistem neuromuscular, mengurangi gejala depresi dan kecemasan, meningkatkan harga diri, meningkatkan citra tubuh dan memberikan kesenangan.

Latihan rentang gerak pasif merupakan salah satu jenis metode dalam melakukan latihan rentang gerak. Jenis metode ini dalam pelaksanaannya memerlukan bantuan untuk memberi latihan kepada sendi yang akan dilatih. Dalam pelaksanaannya, latihan rentang gerak memerlukan bantuan untuk memberi pergerakan pada sendi yang akan diregang. Peregangan dilakukan oleh pasien secara perlahan-lahan sampai limit rasa sakit (rasa sakit yang pertama) dan bukan sampai terasa sakit yang maksimal. Setelah itu barulah peneliti memberi regangan secara perlahanlahan sampai titik fleksibilitas maksimum tercapai (rasa sakit kedua). Pada saat itulah (antara rasa sakit pertama dan rasa sakit kedua) reflex muscle spindle terjadi, sehingga pemanjangan otot tidak dimungkinkan lagi (Dharma, 1984/1993 ; Ganong, 1995).

Muscle spindle merupakan suatu receptor yang menerima rangsang dari regangan otot. Regangan yang cepat akan menghasilkan impuls yang kuat pada muscle spindle. Rangsangan yang kuat akan menyebabkan refleks muscle spindle yaitu 
mengirim impuls ke spinal cord menuju jaringan otot dengan cepat, menyebabkan kontraksi otot yang cepat dan kuat. Muscle spindle sangat berperan dalam proses pergerakan atau pengaturan motorik (Potter \& Perry, 2005).

Berdasarkan hasil penelitian, pada klien fraktur femur terpasang fiksasi interna yang sedang melakukan bedrest atau mengalami keterbatasan dalam pergerakan, latihan pasif sangat tepat dilakukan dan akan mendapatkan manfaat seperti terhindarnya dari kemungkinan terjadinya gangguan fleksibilitas sendi. Setiap gerakan yang dilakukan dengan rentang yang penuh, maka akan meningkatkan kemampuan bergerak dan dapat mencegah keterbatasan dalam beraktivitas. Ketika pasien tidak dapat melakukan latihan secara aktif maka perawat bisa membantu untuk melakukan latihan.

\section{B. Fleksibilitas Sendi Pada Pasien Fraktur Femur Terpasang Fiksasi Interna Yang Melakukan Latihan Rentang Gerak Tidak Sesuai Dengan Aturan Penelitian (Kelompok Kontrol)}

Berdasarkan hasil analisis penelitian dari 10 orang pasien kelompok kontrol, didapatkan hasil dari fleksi sendi panggul dengan nilai maximum 50 derajat dan minimum 40 derajat, pada fleksi sendi lutut di dapatkan nilai maximum 20 derajat dan minimum 10 derajat. Selanjutnya dorsofleksi sendi pergelangan kaki didapatkan nilai maximum 5 derajat dan minimum 0 derajat. Sedangkan untuk plantarfleksi sendi pergelangan kaki di dapat nilai maximum 45 derajat dan minimum 25 derajat.

Berdasarkan teori yang dikemukakan oleh Potter \& Perry (2005), rentang normal fleksi sendi panggul adalah 90- 120 derajat dibandingkan dengan hasil yang didapat ada peningkatan sepertiga bagiannya. Pada sendi lutut di dapatkan rentang normal 120-130 derajat dan dibandingkan dengan hasil latihan yang diberikan pada sendi lutut terlihat tidak terdapat peningkatan yang memuaskan. Selanjutnya, dorsofleksi pergelangan kaki dengan rentang normal 2030 derajat dibandingkan hasil yang didapat juga kurang memuaskan, sedangkan untuk plantarfleksi dengan rentang normal 45-50 derajat, dibandingkan dengan hasil penelitian yang didapat terlihat hanya sebagian saja pasien yang mengalami peningkatan rentang gerak mendekati normal.

Selain disebabkan oleh adanya trauma langsung pada system musculoskeletal yang menyebabkan terjadinya fraktur, juga didapatkan adanya perasaan nyeri akibat adanya incisi (luka operasi) di daerah paha tempat fraktur terjadi disertai dengan dekatnya daerah operasi tersebut dengan daerah sendi anggota gerak bawah, terutama sendi lutut. Hal ini terjadi akibat dalam proses penyembuhan luka masih dalam tahap inflamasi yang berlangsung selama 2-3 hari pasca operasi (Smeltzer \& Bare, 2002).

Setelah pembedahan nyeri mungkin sangat berat, adanya edema, hematom dan spasme otot sehingga hal ini dapat berdampak terjadinya gangguan pada kontraksi dan relaksasi otot. Otot-otot yang penting dalam kontraksi dan relaksasi, bila tidak digerakkan mengakibatkan salah satunya adalah gangguan fleksibilitas sendi (Potter \& Perry, 2005).

Latihan rentang gerak yang dilakukan tidak sesuai aturan penelitian yang dilakukan pasien menampakkan hasil yang kurang menuaskan dalam mengatasi gangguan fleksibilitas sendi. Hal ini dapat dibuktikan dari hasil yang didapat setelah dilakukan pengukuran. Penyuluhan dan cara latihan rentang gerak (lefleat) ada diberikan oleh peneliti, tapi sebagian besar pasien tidak ada melaksanakan. Selain dari hasil 
yang di dapat kurang memuaskan terutama untuk sendi lutut dan dorsofleksi, hal ini ditambah dengan adanya perasaan nyeri yang dialami oleh pasien sendiri dan mengakibatkan pasien malas melakukan latihan rentang gerak.

Dilihat dari karakteristik pasien kelompok kontrol berdasarkan umur dan jenis kelamin separuh pasien $(50 \%)$ berusia 36-45 tahun (dewasa akhir) dan lebih dari separuh responden $(70 \%)$ dengan jenis kelamin laki-laki. Hal ini sesuai dengan teori yang dikemukakan oleh Pudjiastuti dan Utomo, 2003 usia mempengaruhi sistem tubuh termasuk muskuloskeletal. Semakin bertambah usia maka fungsi muskuloskeletal akan semakin berkurang. Setelah mencapai puncaknya maka perlahan-lahan terjadi perubahan fungsi ke arah penurunan.

Kolagen dan elastin sebagai protein pendukung utama pada kulit, tulang, tendon, kartilago dan jaringan pengikat mengalami perubahan menjadi bentangan cross linking yang tidak teratur. Selain kolagen, unsur lain juga berkurang seiring bertambahnya umur. Menurunnya kepadatan tulang, berubahnya struktur otot dan sendi yang lama kelamaan mengalami penurunan elastisitas menyebabkan kekuatan dan fleksibilitas otot sendi menjadi menurun sehingga terjadi penurunan luas gerak sendi. Dan berdasarkan jenis kelamin, wanita cenderung lebih fleksibel dari pada laki-laki pada usia yang sama sepanjang hidup. Perbedaan ini umumnya dikaitkan dengan variasi anatomi dalam struktur sendi.

Secara teori, apabila otot-otot termasuk otot ekstremitas bawah tidak dilatih terutama pada klien yang mengalami gangguan fungsi motorik kasar dalam jangka waktu tertentu maka otot akan kehilangan fungsi motoriknya secara permanen. Hal ini terjadi karena otot cenderung dalam keadaan immobilisasi. Keterbatasan mobilisasi mempengaruhi otot klien melalui kehilangan daya tahan, penurunan massa otot, atrofi dan penurunan stabilitas. Pengaruh lain dari keterbatasan mobilisasi adalah gangguan metabolisme kalsium dan gangguan mobilisasi sendi. Immobilisasi dapat mempengaruhi fungsi otot dan skeletal. Akibat pemecahan protein pada otot, klien mengalami kehilangan massa tubuh yang membentuk sebagian otot.

Oleh karena itu penurunan massa otot tidak mampu mempertahankan aktifitas tanpa peningkatan kelelahan. Massa otot menurun akibat metabolisme dan otot yang tidak digunakan. Jika imobilisasi berlanjut dan otot tidak dilatih maka akan terjadi penurunan massa yang berkelanjutan (Potter \& Perry, 2005). Penurunan mobilisasi dan gerakan mengakibatkan kerusakan muskuloskeletal yang besar dengan perubahan patofisiologi utamanya adalah atrofi.

Atrofi adalah suatu keadaan sebagai respons tehadap penyakit dan penurunan aktifitas sehari-hari seperti pada imobilisasi dan tirah baring (Kasper dkk, 1993 dalam Potter \& Perry, 2005). Penurunan stabilitas terjadi akibat kehilangan daya tahan, penurunan massa otot, atrofi dan kelainan sendi yang aktual sehingga klien tidak mampu bergerak terus menerus dan beresiko untuk jatuh. Seperti yang telah dijelaskan diatas, bahwa imobilisasi dapat menyebabkan gangguan metabolisme kalsium dan sendi. Akibatnya resorpsi tulang menjadi meningkat sehingga jaringan tulang kehilangan kepadatannya dan terjadi osteoporosis (Holm, 1989 dalam Potter \& Perry, 2005).

Dampak imobilisasi juga dapat mengakibatkan kontraktur sendi yaitu suatu kondisi abnomal dan permanen yang ditandai dengan fleksi sendi dan terfiksasi. Hal ini terjadi akibat sendi tidak digunakan, atrofi dan terjadi pemendekan serat otot. Jika terjadi kontraktur maka sendi tidak dapat mempertahankan rentang geraknya dengan penuh. Besarnya keuntungan yang didapat 
dari latihan rentang serta dampak yang ditimbulkan, maka jelaslah bahwa latihan rentang gerak sangat dianjurkan untuk dilakukan secara teratur terutama pada klien dengan gangguan fungsi motorik termasuk pada pasien fraktur femur terpasang fiksasi interna. Karena dengan latihan ini maka fungsi motorik menjadi meningkat sehingga pasien dapat melakukan mobilisasi dengan lebih baik untuk menunjang aktifitas sehariharinya.

\section{Perbedaan Fleksibilitas Sendi Pada Pasien Fraktur Femur Terpasang Fiksasi Interna Setelah Pemberian Latihan Rentang Gerak Dengan Yang Melakukan Latihan Rentang Gerak Tidak Sesuai Dengan Aturan Penelitian}

Hasil analisis data pada table 6 didapatkan rata-rata rentang fleksi pinggul pada kelompok eksperimen adalah 15.5 derajat, sedangkan pada kelompok kontrol adalah 5.5. hasil uji statistic Mann Whitney dapat disimpulkan ada perbedaan yang signifikan rentang fleksi pinggul antara kelompok eksperimen dan kelompok control $(p$ value $=0.001<0.05)$. Hasil analisis data pada table 7 didapatkan rata-rata rentang fleksi lutut pada kelompok eksperimen adalah 15.5 derajat, sedangkan pada kelompok kontrol adalah 5.5 derajat. Hasil uji statistik Mann Whitney dapat disimpulkan ada perbedaan yang signifikan rentang fleksi lutut antara kelompok eksperimen dan kelompok kontrol ( $p$ value $=0.001<0.05)$. Hasil analisis data pada table 8 didapatkan rata-rata rentang gerak dorsofleksi pada kelompok eksperimen adalah 15,35 derajat, sedangkan pada kelompok kontrol adalah 5.65. Hasil uji statistic Mann Whitney dapat disimpulkan ada perbedaan yang signifikan rentang gerak dorsofleksi antara kelompok eksperimen dan kelompok control $(p$ value $=0.000<0.05)$.
Hasil analisis data pada table 9 didapatkan rata-rata rentang plantarfleksi pada kelompok eksperimen adalah 14.9 derajat, sedangkan pada kelompok kontrol adalah 6.1. Hasil uji statistic Mann Whitney dapat disimpulkan ada perbedaan yang signifikan rentang gerak plantarfleksi antara kelompok eksperimen dan kelompok control ( $p$ value $=0.001<0.05)$.

Berdasarkan hasil analisis diatas maka dapat disimpulkan bahwa latihan rentang gerak yang dilakukan selama tiga hari berturut turut dengan frekuensi 2 kali sehari dapat meningkatkan fleksibilitas sendi panggul, lutut, dorsofleksi dan plantarflksi pergelangan kaki secara bermakna pada pasien fraktur femur terpasang fiksasi interna yang mengalami gangguan motorik. Walaupun kenaikan nilai rentang tidak terlalu besar tetapi hasil ini cukup membuktikan bahwa intervensi yang dilakukan memberikan hasil yang diharapkan. Hal ini berbeda dibandingkan dengan kelompok kontrol yang hanya melakukan latihan rentang gerak tidak sesuai dengan aturan penelitian dimana setelah dilakukan pengukuran nilai fleksibilitas sendi terdapat kenaikan tetapi kenaikannya sangat kecil dibandingkan dengan kelompok intervensi.

Penelitian ini sejalan dengan penelitian yang dilakukan oleh Kelln, et al (2009) yang menyatakan bahwa pelaksanaan program latihan rentang gerak secara dini pada klien pasca pembedahan menghasilkan suatu peningkatan yang signifikan bagi pemulihan yang lebih cepat. Peningkatan yang terlihat diantaranya adalah cara berjalan yang lebih baik, peningkatan dalam fleksi panggul, lutut, dorsofleksi dan plantarfleksi kearah normal, walaupun secara statistik tidak memberikan pengaruh yang signifikan terhadap peningkatan ketebalan ekstremitas dan luas gerak sendi lutut. Kesimpulannya adalah intervensi ini memberikan efek positif dan harapan bagi 
klien dengan gangguan sendi bahwa dengan latihan rentang gerak secara dini yang dilakukan minimal selama 3 hari pasca pembedahan dapat mempercepat pemulihan kearah normal.

Secara teori, latihan rentang gerak yang dilakukan secara rutin sangat penting karena tujuan utama latihan rentang gerak adalah untuk memelihara sendi agar tetap fleksibel. Latihan ini juga dapat membantu sendi agar tidak kaku, kontraktur serta menghindari deformitas. Bahaya paling besar ketika terjadi paralisis atau spastis yang menyebabkan ketidakseimbangan otot, dimana sendi tertarik lebih kuat ke satu arah sehingga menekuk secara terus menerus (Werner, 2009). Keadaan ini akan mengakibatkan sendi kehilangan elastisitasnya sehingga fleksibilitas sendi menjadi menurun.

Kontraktur merupakan gangguan yang umum terjadi pada klien dengan pasien fratur femur pasca pembedahan. Kontraktur bisa berupa kontraksi otot yang permanen, tahanan yang tinggi pada peregangan pasif, hipoekstensibilitas, berkurangnya rentang peregangan pasif dan pemendekan otot. Untuk mencegah terjadinya kontraktur dan deformitas, latihan rentang gerak harus dilakukan secara kontinyu. Penting bagi pasien fraktur femur terpasang fiksasi interna untuk menggerakan tubuhnya melalui pergerakan sendi secara penuh dalam aktifitas kehidupan sehari-hari (Werner, 2009). Menurut Bowden \& Greenberg (2008) agar sendi tidak kehilangan fungsinya, maka latihan rentang gerak sebaiknya dilakukan setidaknya 2 kali dalam sehari. Jika sendi telah kehilangan gerakannya, maka latihan dilakukan lebih sering dan lebih lama. Latihan rentang gerak harus dilakukan sedini mungkin sebelum sendi kehilangan rentang geraknya. Memulai latihan sedini mungkin dapat mengurangi dan mencegah terjadinya keterbatasan. Selain melihat pengaruh latihan rentang gerak terhadap fleksibilitas sendi panggul, lutut, dorsofleksi, dan plantarfleksi pergelangan kaki dan masing-masing kelompok, pada penelitian ini juga membandingkan bagaimana pengaruh latihan rentang gerak antara kelompok intervensi dan kelompok kontrol. Hasilnya menunjukkan bahwa ada perbedaan rentang gerak antara kelompok intervensi dan kontrol. Hasil analisis menunjukkan bahwa rata-rata nilai fleksibilitas sendi panggul, sendi lutut, dorsofleksi dan plantarfleksi sendi pergelangan kaki kelompok intervensi lebih tinggi bila dibandingkan dengan kelompok control.

Berdasarkan hasil penelitian diatas, maka peneliti dapat menyimpulkan bahwa latihan rentang gerak efektif harus dilaksanakan dalam membantu mencegah terjadinya gangguan fleksibilitas sendi pada pasien pasca operasi terpasang fiksasi interna. Latihan rentang gerak merupakan salah satu intervensi keperawatan "Gangguan mobilitas fisik" dimana pasien mengalami ketidakseimbangan atau keterbatasan dalam menggerakkan satu atau lebih bagian sendi (Ellis \& Bent, 2007). Hal ini didukung oleh penelitian yang dilakukan oleh Jogi (2010) yang melakukan intervensi latihan rentang gerak sendi pada klien post Total Hip Arthroplasty (THA) dan Total Knee Arthroplasty (TKA) kepada 30 pasien. Latihan dilakukan sebanyak 1-2 kali seminggu selama 5-7 minggu. Hasilnya terjadi peningkatan secara signifikan pada keseimbangan dan kekuatan otot terutama pada saat posisi berdiri.

Latihan rentang gerak dapat diberikan pada pasien yang mengalami keterbatasan mobilisasi, dan tidak mampu melakukan beberapa atau semua latihan rentang gerak dengan mandiri. Untuk itu perawat harus membuat jadwal kapan latihan rentang gerak harus dilakukan. Berdasarkan obsevasi peneliti dilapangan hal-hal yang menghambat dalam 
pelaksanaan latihan retang gerak seperti adanya nyeri pasca pembedahan dan daerah trauma dapat ditepis dengan cara melakukan latihan rentang gerak pasif secara perlahan dan lembut sehingga tidak menimbulkan perasaan nyeri pada pasien. (Potter \& Perry, 2005).

Latihan rentang gerak yang diberikan dalam penelitian ini cukup mendapat respon yang baik dari responden, keluarga dan petugas Trauma Centre sendiri. Pelaksanaan latihan rentang gerak ini juga didukung dengan pedoman yang disertai gambar, sehingga memudahkan responden dan petugas untk melaksanakannya.

\section{KESIMPULAN DAN SARAN}

\section{A. Kesimpulan}

Berdasarkan hasil penelitian yang dilakukan tentang pengaruh pemberian latihan rentang gerak terhadap fleksibilitas sendi anggota gerak bawah pada pasien fraktur femur terpasang fiksasi interna di Ruang Trauma Centre RSUP Dr. M. Djamil Padang, maka dapat diambil kesimpulan sebagai berikut:

1. Pada kelompok eksperimen didapatkan rata-rata fleksibilitas sendi setelah

diberikan latihan rentang gerak yaitu pada fleksi sendi panggul 68,5 derajat, fleksi sendi lutut 61 derajat, dorsofleksi pergelangan kaki 12,5 aderajat dan plantarfleksi pergelangan kaki 47 derajat.

2. Pada kelompok kontrol didapatkan rata-rata fleksibilitas sendi setelah dilakukan gerakan tidak sesuai aturan penelitian yaitu fleksi sendi panggul 45,5 derajat, fleksi sendi lutut 15,5 derajat, dorsofleksi pergelangan kaki 1,5 derajat dan plantarfleksi pergelangan kaki 33,5 derajat.
3. Adanya perbedaan yang bermakna fleksibilitas sendi anggotak gerak bawah antara kelompok eksperimen yang diberikan latihan rentang gerak dengan kelompok kontrol yang melakukan latihan rentang gerak tidak sesuai aturan penelitian.

\section{B. Saran}

1. Bagi Profesi Keperawatan

Adanya peningkatan

pengetahuan perawat khususnya untuk orthopedi melalui pelatihan atau seminar sehingga mendapatkan keterampilan yang sama dalam merawat pasien pasca operasi ekstremitas bawah terutama bagaimana mengoptimalkan latihan rentang gerak untuk mencegah terjadinya masalah gangguan fleksibilitas sendi.

2. Bagi Instansi Rumah Sakit

Hasil penelitian ini dapat dilanjutkan sebagai intervensi dirumah sakit untuk menerapkan pelaksanaan latihan rentang gerak secara terstruktur dan terencana dan membuat kebijakan dalam bentuk SOP.

3. Bagi penelitian selanjutnya

a. Perlunya penelitian tentang terapi lain untuk meningkatkan fleksibilitas sendi dan rentang gerak ekstremitas bawah pada pasien fraktur femur, misalnya penggunaan biofeeback, akupuntur, atau continuous passive motion.

b. Perlunya penelitian tentang perbandingan tingkat efektifitas latihan rentang gerak dengan terapi lainya seperti latihan rentang gerak dengan akupresur dalam

meningkatkan 
fleksibilitas sendi ekstremitas bawah pada pasien fratur femur post operasi.

\section{KEPUSTAKAAN}

Berger \& Williams. (1992). Fundamental of nursing: Collaborating for optimal helath. USA: Apleton \& Lange

c. Bowden, V.R \& Greenberg, C.S. (2008). Pediatric nursing procedures. second edition. Philadelphia: Lipincot William and Wilkins.

d. Cluett, J. (2008). Open Reduction Internal Fixation. Diakses pada tanggal 8 November 2012, dari http://orthopedics.about.com/ cs/brokenbones

e. Dahlan, M. S. (2011). Statistik untuk kedokteran dan kesehatan: Deskriptif, bivariat, dan multivariat, dilengkapi aplikasi dengan menggunakan SPSS. Jakarta: Salemba Medika.

f. Ellis, JR \& Bentz, PM. (2007). Modules for basic nursing skills. Philadelphia: Lippincoat Williams \& Wilkins.

g. Fakultas Keperawatan. (2012). Pedoman penulisan skripsi. Padang: Universitas Andalas.

h. Faridaryany. (2010). Anatomi fisiologi sistem muskuloskeletal: Mata kuliah biomedik II. Diakses tanggal 9 Januari 2013, dari files.wordpress.com/ 2012/06/anfis-muskuloskeletal.

i. Fatmah. (2010). Gizi usia lanjut. Jakarta: Erlangga.

j. Ganong. (1995). Anatomi Fisiologi. Jakarta: EGC

k. Hastono, S.P. (2007). Analisis data kesehatan. Jakarta: FKM UI
1. Iryani, D. (2010). Fisiologi anatomi otot rangka: Mata kuliah pengantar. Diakses tanggal 9 Januari 2013, dari fkunand 2010.files.wordpress.com

m. Kelln, B.M, (2009). Effect of early active range of motion rehabilitation on outcome measures after partial meniscectomy. Knee Surg Sports Traumatol Arthrosc, 17 (35), 607-616.

n. Kozier, B., dkk. (2010). Buku ajar fundamental keperawatan: Konsep, proses, \& praktik (7th ed, 2nd vol.). Jakarta: Buku Kedokteran EGC.

o. Lewis, S. L, dkk. (2011). Medical-surgical nursing: Assessment and management of clinical promlems (8th ed, 2nd vol.). America: Elsevier Mosby.

p. Muttaqin, A. (2008). Buku ajar asuhan keperawatan klien gangguan sistem muskuloskeletal. Jakarta: Buku Kedokteran EGC.

q. Notoatmodjo, S. (2010). Metodologi penelitian kesehatan. Jakarta: Rineka Cipta.

r. Nursalam. (2008). Konsep dan penerapan metodologi penelitian ilmu keperawatan: pedoman skripsi, tesis, dan instrumen penelitian keperawatan. Jakarta: Salemba Medika.

s. Oldmeadow, dkk. (2006). No rest for the wounded: early ambulation after hip surgey accelerates recovery. Diakses pada tanggal 5 Mei 2013 dari http://proquest.umi.com/pqdweb 
t. Pearce, E. C. (2000). Anatomi dan fisiologi untuk paramedis. Jakarta: PT Gramedia.

u. Potter, P. A., \& Perry,A. G. (1993). Fundamental of nursing: concepts, proces, \& practice (3rd ed.). America: Mosby-Year Book, Inc.

v. Potter, P. A., \& Perry, A. G. (2005). Buku ajar fundamental keperawatan: konsep, proses, \& praktik. Jakarta: Buku Kedokteran EGC.

w. Pudjiastuti, S. S \& Utomo, B. (2003). Fisioterapi pada lansia. Jakarta: EGC.

x. Riwidikdo, H. (2012). Statistik kesehatan: Belajar mudah teknik analisis data dalam penelitian kesehatan. Jakarta: EGC

y. Sjamsuhidajat, R., \& Jong, W. d. (2005). Buku-ajar ilmu bedah (2nd.). Jakarta: Buku Kedokteran EGC.

z. Smeltzer, S. C., \& Bare, B. G. (2002). Buku ajar keperawatan medikal-bedah brunner \& suddarth (8th, 3rd vol.). Jakarta: Buku Kedokteran EGC.

aa. Solamon, L., Warwick, D., \& Nayagam, S. (2001). Apley's System of Orthopaedics and Fractures (8th ed.). New York: Oxford University Press, Inc.

bb. Astuti. (2006). Pengaruh latihan rentang gerak terhadap kekuatan otot dan luas rentang gerak pada pasien stroke di RSU Soetomo Surabaya. Diakses pada tanggal 20 April 2013, dari lontar.ui.ac.id/file? file $=$ digital/1 $37247 p d f$

cc. Timby, B.K. (2009). Fundamental nursing skills and concepts. Philadelphia:
Lippincoat Williams and Wilkins

dd. Tseng, dkk. (2007). Effects of a range of-motion exercise programme. Journal of Advanced Nursing, 57(2), 181191.

ee. Ulliya, S. (2010). Pengaruh latihan range of motion (rom) terhadap fleksibilitas sendi lutut pada lansia di Panti Wreda Wening Wardoyo Ungaran. Diakses tanggal 10 Februari 2013, dari http://ejournal.undip.ac.id/index

ff. Werner, D. (2009). Disabled village children a guide for community health workers, rehabilitation workers, and families. California: The Hesperian Foundation.

gg. Widyawati, I. Y. Pengaruh latihan rentang gerak sendi bawah secara aktif (Active lower range of motion exercise) terhadap tanda dan gejala neuropati diabetikum pada penderita DM tipe II Di Persadia Unit RSU Dr. Soetomo Surabaya. Diakses pada tanggal 20 April 2013, dari lontar.ui.ac.id/file? file $=$ digit al/137247 pdf

hh. Yandri, E. (2011). Faktor-faktor yang mempengaruhi kontraktur sendi lutut pada penanganan fraktur femur secara operatif dan non operatif. Padang: Fakultas Kedokteran Universitas Andalas

ii. Yanwirasti. (2010). Tulang dan persendian extremitas inferior. Diakses pada tanggal 9 Januari 2013, dari files.wordpress.com. 